\section{World Health Day 1997: Emerging infectious diseases $^{1}$}

Source: World Health Organization. World Health Day 1997 Information Kit. Geneva: WHO; 1997.
Until recently, there was widespread optimism that the struggle against infectious diseases was almost won. This optimism, fueled by progress such as the global eradication of smallpox and dramatic reductions in the incidence of other diseases, has in some cases led to complacency, allowing diseases like malaria and tuberculosis to make a comeback in many parts of the world. In addition, previously unknown infectious diseases are appearing at an alarming rate: more than 30 in the past 20 years. At the same time, disease-causing organisms have become resistant to a wider spectrum of antibiotics. All of this is happening at a time when public health resources are shrinking in both rich and poor countries.

In view of the threat posed by these factors, the World Health Organization has selected the theme "Emerging Infectious Diseases-Global Alert, Global Response" for World Health Day 1997. Celebrated on 7 April in observance of the formal adoption of the WHO constitution in 1948, this annual event calls attention to a health topic of global importance. In his World Health Day message, the Director-General of WHO expresses the hope that this year's theme will serve as a catalyst for countries to take a realistic look at infectious disease problems and concentrate on rebuilding the foundations of disease surveillance and control.

\section{CURRENT PROBLEMS AND RESPONSES}

Emerging infectious diseases are those caused by newly identified and previously unknown infections. Recent examples include a highly fatal respiratory disease caused by a hantavirus, which came to light in the southwestern United States of America in 1993; a variant of Creutzfeldt-Jakob disease (a central nervous system affliction), which is suspected, though not proven, to be associated with a similar disease in cattle (bovine spongiform encephalopathy, popularly referred to as "mad cow disease"); HIV infection, which causes AIDS; and Ebola hemorrhagic fever. It is not always possible to know if these diseases are new in humans or whether they have been present but unrecognized for a long time.

In contrast, re-emerging infectious diseases are those which are once again becoming common after having fallen to levels so low that they were no longer considered a public health problem. These diseases often reappear in epidemic propor- 
tions. Tuberculosis is increasing worldwide, in part because of its association with HIV infection. Cholera was reintroduced in 1991 into many countries of the Americas after having been absent for decades from the Western Hemisphere; its spread has been encouraged by deficiencies in water and sanitation systems. Epidemics of dengue fever have recurred in urban areas where mosquito control has broken down.

\section{Causes of emergence and re-emergence of infectious diseases}

Several factors contribute to the emergence and re-emergence of infectious diseases, but most can be linked to the increasing human population: rapid and heavy international travel; overcrowding in cities with poor sanitation; changes in the way large quantities of food are handled and processed; and increased exposure of humans to disease vectors and natural reservoirs. Closer contact of humans with the natural reservoirs of an infectious agent sets the stage for the agent to "jump" across the species barrier from animals to humans.

These problems are compounded by the development and spread of antibiotic-resistant microorganisms. Many well-known antibiotics are no longer effective in treating common infections, such as otitis, pneumonia, gonorrhea, and tuberculosis. At the same time, fewer new antibiotics are released on the market, partly because of the high cost of developing and licensing them and because microbial resistance reduces the "useful life" of antibiotics. The misuse of antibiotics exacerbates the problem of resistance.

All of these factors have been observed in the past few decades, together with a waning concern (and decreased resources) for infectious disease control. During the first half of the 20th century, deaths from infectious diseases declined steadily because of improved hygiene and nutrition. This trend was strengthened with the advent of a growing number of vaccines and antibiotics. Because infectious diseases appeared to be a decreasing threat, funds for their control were channeled toward other problems, and as experts retired, fewer students entered the field. The infrastructure for communicable disease control began to crumble and in many places it has become unable to cope with the demands imposed by a growing population and new disease threats.

\section{The global response}

Alarm over emerging and re-emerging diseases has resulted in a number of national and international initiatives in the past five years to restore and improve surveillance and control of communicable diseases. The Member States of WHO expressed their concern in a resolution of the 48th World Health Assembly in 1995, which urged all Member States to strengthen surveillance for infectious diseases in order to promptly detect reemerging diseases and identify new ones. That same year PAHO prepared a Regional Plan of Action for Combatting New, Emerging, and Reemerging Infectious Diseases in the Americas, which will serve as PAHO's blueprint for implementing programs and initiatives on emerging infections in the Western Hemisphere.

The success of efforts to combat infectious diseases depends on the ability to obtain information on them and the willingness to communicate that information nationally and internationally. In furtherance of the World Health Assembly resolution, WHO established the Division of Emerging and Other Communicable Diseases Surveillance and Control (EMC), whose mission is to strengthen national and international capacity in these areas in order to ensure a timely and effective response to emerging and re-emerging public health problems.

A worldwide partnership of countries, nongovernmental organizations, international organizations, and individuals is required to respond to the threat of emerging and re-emerging diseases by ensuring rapid detection and effective containment. The World Health Organization, as one of the partners in this global effort, is strengthening global monitoring systems to serve as part of the overall detection system. Three independent systems are already in existence, bringing together specialized laboratories and disease surveillance systems from all countries and feeding information electronically to the World Wide Web and other international electronic and printed media.

WHO Collaborating Centers. One of these global systems is the network of WHO Collaborating Centers, which include specialized laboratories and institutions with expertise in infectious disease diagnosis and epidemiology. During recent epidemics, it has become clear that the WHO system of Collaborating Centers could no longer fully respond to global needs. For example, some centers had failed to keep up with changes in technology and were unable to provide the diagnostic support necessary to confirm the etiology of disease outbreaks. Other centers did not have sufficient expertise in the epidemiology of some of the newer infectious diseases. Moreover, there are not enough Collaborating Centers in developing countries to ensure self-sufficiency within all regions. WHO is therefore asking governments to provide the 
resources necessary to bring the Collaborating Centers up-to-date. WHO is also facilitating the exchange of information and reagents among centers, increasing the number of centers in developing countries, and ensuring that all centers are linked electronically and regularly exchange information.

Antimicrobial resistance monitoring. The second global system includes the WHO networks for monitoring and containing antimicrobial resistance: WHONET, for the monitoring of general antimicrobial resistance, and GASP, the program for monitoring gonococcal antibiotic susceptibility. Increasing antimicrobial resistance results in higher costs because of the use of more expensive combinations of antibiotics, increased rates of hospitalization for infections once easily treated on an outpatient basis, and time lost from work or school until cure. Through WHONET and GASP, WHO regularly obtains standardized and reliable information on the current state of antimicrobial resistance, helps countries use this information to formulate sound national drug policies, and uses the information internationally to identify problems and advocate antibiotic research and development.

International Health Regulations. The third system is represented by the International Health Regulations (IHR), currently the only international public health legislation which requires reporting of infectious diseases. Only three diseases are covered by the IHR: cholera, plague, and yellow fever. WHO has no legal mandate to force reporting and some countries are reluctant to report cases of these diseases owing to negative repercussions such as restrictions on trade and travel. WHO is currently rewriting the IHR to convert them into a true global alert system, in which reporting will be encouraged and all globally important diseases will be reported. Clear and concise guidelines for countries are also being developed, describing both appropriate and inappropriate responses to clinical syndromes that are reported.

\section{CHALLENGES AND SOLUTIONS AHEAD}

To confront the challenges posed by communicable diseases, the vision for the 21st century is a world on the alert and able to cope with communicable diseases through a combination of the following mechanisms: strong national disease surveillance and control programs; global networks to monitor and alert the world to infectious diseases and related public health problems; rapid information exchange through electronic links; and effec- tive preparedness and rapid response to contain epidemics of international importance.

Between the world of today and this vision of the 21st century lies a huge gap. The possibility of bridging this gap depends on the forging of committed partnerships among individuals, organizations, and countries, with the backing of PAHO, $\mathrm{WHO}$, and other agencies. The challenges and the international responses that are required to meet them are outlined below.

\section{Early detection of epidemics}

In an environment with poor public health infrastructure, an unusual disease may not be detected until it has become a major threat to the population and cannot be contained with national resources. Public health laboratories, where they exist, are often poorly equipped or unable to diagnose common diseases and assess their impact on the community.

There is a need for improved national infrastructure for routine surveillance of common diseases, including the strengthening of public health laboratory services and training to increase the pool of staff capable of maintaining routine surveillance on a national scale. Surveillance provides the background data against which uncommon events can be identified.

\section{Rapid national response to unusual disease events or outbreaks}

Even when an unusual disease or outbreak is reported to local or national health authorities, it may not trigger a response, or the response may be inadequate or late. For that reason, it is necessary to train key national staff, assess surveillance systems, and prepare plans to contain future outbreaks before they become national emergencies. In addition to these long-term activities, international agencies such as PAHO and WHO, along with their partners, will need to play an active role in the management of outbreaks through provision of expert advice, diagnostic reagents, vaccines and drugs, and an international response team if needed, and evaluation of the response in order to improve future performance.

\section{Efficient and viable national surveillance systems}

Many countries lack a national, uniform surveillance system for the routine monitoring of communicable diseases. Data and information from a 
fractionated and poorly integrated system do not provide disease alerts or allow for global monitoring of communicable diseases, nor do they help national authorities in setting public health policies.

There is a need to develop surveillance guidelines with internationally accepted case definitions, and to stimulate the use of these guidelines through workshops for key regional and national staff. The flow of information to and from national surveillance systems within a global network must be facilitated and coordinated.

\section{Timely health information}

Outbreaks of communicable diseases have become news. The media are sometimes the only source of information on outbreaks, but inaccurate reports have hindered evaluation of the true situation and the need for intervention. Official information has sometimes been difficult to obtain, either because it does not exist or because it could not be cleared for release.

An open, responsible exchange of information must be advocated to facilitate national reporting of outbreaks. Reliable and relevant information on diseases and outbreaks should be made available to the world community through electronic and conventional media, supplemented with appropriate advice to people living in or traveling to the affected areas.

\section{Sound international reactions to outbreaks}

The international community has sometimes reacted with panic to outbreaks of cholera, Ebola hemorrhagic fever, and plague, setting up inappropriate barriers to travel and trade, including quarantine at airports. These measures cause heavy losses in tourism and export without providing much real protection against the importation of the disease.

There is a need to revise the International Health Regulations to provide an internationally agreed-upon code of practice and control of the international spread of potentially dangerous infectious diseases, according to today's epidemiologic and economic realities. Guidelines must be provided on the application of the IHR to minimize the disruption of travel and trade that has been a strong disincentive to alerts in the past.

\section{International infrastructure}

As public health priorities changed in the 1970s and 1980s, resources for communicable dis- ease control became scarce and the necessary infrastructure weakened. WHO's network of Collaborating Centers is an important component of this infrastructure. Strengthening of the WHO Collaborating Centers is required to provide high-quality reference services for diagnosis, training, and intervention in outbreaks. Identifying new laboratories to extend the network and establishing electronic links to facilitate the flow of data are also required.

\section{Antimicrobial resistance}

Antibiotic-resistant bacteria appeared almost as soon as antibiotics began to be used. The emergence of resistant bacteria has accelerated in the past two decades. To combat this problem, the use of programs that accurately monitor the frequency and geographical distribution of antimicrobial resistance must be extended. Users of the programs will need to be linked in an international surveillance network so that data can be generated to enable the development of national and global strategies and guidelines for the appropriate use of antimicrobials in humans and animals. Research is needed to improve the number of drugs available and to develop alternative ways of preventing and treating infections.

\section{Disease emergence through contact with animals}

The intensified production of animals for food has increased the risks that diseases in animals are transmitted to humans through the food chain. Moreover, as forests are cut down, the animals living there invade habitats close to human populations, and humans penetrate deeper into the remaining forested areas for work or leisure. These circumstances highlight the need to strengthen surveillance of communicable and zoonotic diseases, to seek international consensus on policies to prevent and contain transmission of animal diseases to humans, and to prepare guidelines for the use and management of animals reared for human consumption.

\section{SINOPSIS}

\section{Día Mundial de la Salud 1997: Enfermedades infecciosas emergentes}

Para el Día Mundial de la Salud de 1997, la Organización Mundial de la Salud (OMS) ha elegido el tema "Enfermedades infecciosas emergentes; alerta mundial, respuesta mun- 
dial" con el fin de llamar la atención hacia la amenaza que representan algunas enfermedades infecciosas recientemente reconocidas en seres humanos y otras que han vuelto a aparecer. En la emergencia y reemergencia de enfermedades infecciosas intervienen factores como el deterioro de la infraestructura de salud pública, la creciente resistencia microbiana a los antibióticos y los cambios sociales y ecológicos asociados con el crecimiento de la población humana. La OMS ha hecho hincapié en la necesidad de que se compromentan a entrar juntos en acción tanto países como organizaciones internacionales, organizaciones no gubernamentales e individuos, con objeto de mejorar la vigilancia de las enfermedades y la capacidad de controlarlas para prevenir $y$ refrenar las epidemias. Por su parte, la OMS está reforzando su sistema de vigilancia mundial tripartito, que consta de los centros de colaboración de la OMS en el área de enfermedades infecciosas, las redes de monitoreo de resistencia antimicrobiana y el Reglamento Sanitario Internacional.

Para hacer frente adecuadamente al problema de las enfermedades infecciosas durante el siglo próximo, se necesitarán programas de vigilancia y control; redes mundiales de monitoreo y notificación; rápido intercambio de información por vía electrónica (incluida la World Wide Web); y un estado de preparación efectivo con la capacidad para responder rápidamente a las epidemias y contenerlas.

\section{Fundación Mario Molina para las Ciencias Ambientales: becas de nivel doctoral o posdoctoral}

El Gobierno de México ha anunciado la formación de la Fundación Mario Molina para las Ciencias Ambientales, creada en honor del investigador mexicano-americano Mario Molina Pasquel, ganador del Premio Nobel en Ciencias Químicas en 1995. La Fundación está destinada a apoyar a estudiantes y a investigadores distinguidos en el campo de las ciencias ambientales durante sus estudios doctorales o posdoctorales fuera de México.

El Consejo Nacional de Ciencia y Tecnología (CONACYT) de México y la empresa Petróleos Mexicanos (PEMEX) acordaron facilitar US\$ 1 millón como inversión inicial en la Fundación. Esta cuenta también con US\$100 000, una tercera parte de las ganancias del Premio Nobel, donados por el doctor Molina y US\$ 500000 contribuidos por la Iniciativa Global para el Manejo Ambiental (GEMI), grupo integrado por Cementos Mexicanos, Colgate, Dow Químicas de México, General Electric, GIRSA, Grupo Modelo, Kodak de México, Procter y Gamble, y Tetra Pack. Se espera que GEMI incremente sus contribuciones obteniendo donaciones de otras empresas.

Esta iniciativa refleja el interés del Gobierno y la industria de México en respaldar a los talentos nacionales en ciencia y tecnología, lo cual es indispensable para un desarrollo nacional verdadero. Los requisitos relacionados con la obtención de las becas se anunciarán en un futuro cercano. 